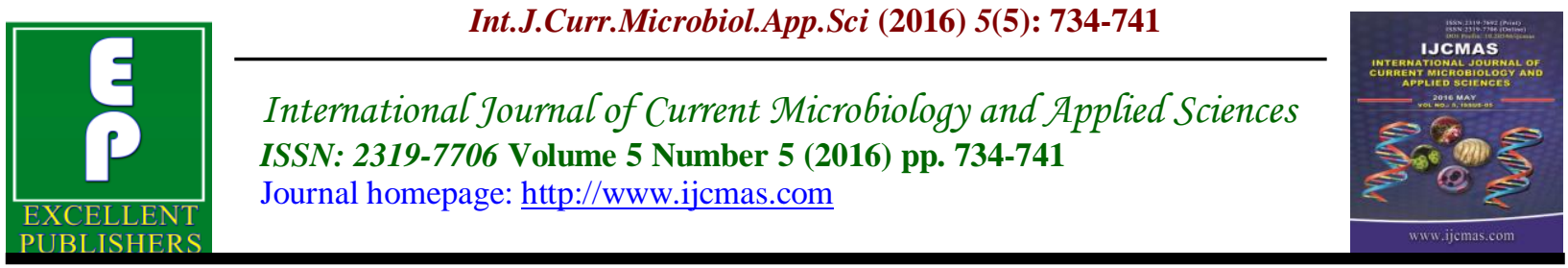

Original Research Article

http://dx.doi.org/10.20546/ijcmas.2016.505.074

\title{
Production of Lactic Acid from Whey by Lactobacillus sp. Isolated from Local Dairy Products
}

\author{
Sweta A. Patel* and Samir C. Parikh \\ P. G. Centre in Microbiology, Smt. S. M. Panchal Science College, Talod.-383215, \\ Dist. Sabarkantha, Gujarat, India \\ *Corresponding author
}

\begin{tabular}{|c|c|}
\hline & A B S T R C T \\
\hline $\begin{array}{l}\text { Lactic acid, } \\
\text { Whey, } \\
\text { Lactobacillus sp. } \\
\text { dairy products. }\end{array}$ & \multirow{3}{*}{$\begin{array}{l}\text { A large volume of whey containing high energy protein and milk sugar is } \\
\text { discharged from dairy industry, which causes environmental pollution and also } \\
\text { economic loss. Whey may be utilized for lactic acid production having wide range } \\
\text { of applications. The aim of this work was to study the fermentation of whey for the } \\
\text { production of lactic acid using newly isolated Lactobacillus bacteria. The effect of } \\
\text { different process parameters such as } \mathrm{pH} \text { of the medium, temperature, inoculums } \\
\text { size, and incubation time was monitored to enhance the conversion from whey } \\
\text { sugar to lactic acid. Lactic acid production was } 29.6 \mathrm{gm} / \mathrm{L} \text { at after an incubation } \\
\text { period of } 72 \mathrm{~h} \text { as compared to commercial strain Lactobacillus delbrukii MTCC } \\
911 \text { was produce lactic acid } 12.22 \mathrm{gm} / \mathrm{L} \text { after } 24 \mathrm{~h}(\text { Guha et al., 2013). }\end{array}$} \\
\hline Article Info & \\
\hline $\begin{array}{l}\text { Accepted: } \\
\text { 20 April } 2016 \\
\text { Available Online: } \\
10 \text { May } 2016\end{array}$ & \\
\hline
\end{tabular}

\section{Introduction}

Milk and milk products provide a wealth of nutrition benefits with their healthy contents along with the micro-flora these products carry. There are a variety of bacteria that can be present in milk and milk products. Lactic acid bacteria (LAB) are commonly associated with fermented dairy products such as cheese, buttermilk, curd, srikhand etc. which enhance the value of the products in terms of nutrition. Lactic acid bacteria (LAB) have the property to convert natural sugars into lactic acid by fermentation. When milk is left to stand, acidity increases due to the presence of LAB (Ohris and Joshi, 1961).
This acidity is due to the presence of lactic acid which was firstly discovered in sour milk in 1780 by a Swedish chemist, Carl Wilhelm Scheele, who initially considered it as milk component which was in 1857 corrected by Louis Pasteur as a fermentation end product (Wee, 2006). The production of lactic acid has been used for a long time in food production (e.g., yogurt, cheese, sauerkraut, sausage). Lactic acid can be produced by either microbial fermentation or chemical synthesis, a great deal of interest has recently become focused on the microbial fermentation, because the chemical synthesis of lactic acid is 
associated with several serious problems, including environmental issues and the depletion of petrochemical resources. Chemical synthesis from petrochemical resources always results in racemic mixture of DL-lactic acid, which is a major disadvantage of this approach (Hofvendahl and Hahn-Hagerdal, 2000). The fermentation process is becoming more relevant because the raw materials used in fermentation are renewable in contrast to petrochemicals. Furthermore, the fermentation process could produce optically pure isomers of lactic acid by selecting an appropriate strain (Ilmen, 2007). Pure isomers, L or D lactic acid, are more valuable than the racemic DL form because each isomer has its own applications in the cosmetics and pharmaceuticals industries. For example, the ratio of $\mathrm{L}-$ and $\mathrm{D}$-lactic acids influences the properties and the degradability of polylactic acids (Kharras, 1993).

Lactic acid is widely used in almost every segment of the food industry, where it serves in a wide range of functions, such as flavouring, $\mathrm{pH}$ regulation, improved microbial quality and mineral fortification. Moreover, lactic acid is used commercially in the processed meat, hams, fish and poultry industries to provide products with an increased shelf life, enhanced flavour, and better control of food-borne pathogens. Due to the mild acidic taste of lactic acid, it is also used as an acidulant in salads and dressings, baked goods, pickled vegetables, and beverages. Lactic acid is under increasing demand in Food, Pharmaceutical and Chemical Industries and for production of Poly lactic acid polymers, which possess outstanding biomedical applications. The global manufacture of this organic acid is estimated to be 45 million kilogram/yr and is expected to grow by $8.6 \%$ annually (Narayanan, 2004). In India, the annual production capacity of lactic acid is 6000 tons and estimate gaps of 2300 tons in supply by the year 2015 have been predicted, if the present level of production is not increased (TIFAC, Code No. TMS 157, 4, Vision 2020 reports).

Lactic acid bacteria have the property of producing lactic acid from sugars by a process called fermentation. Lactic acid bacteria are group of Gram positive bacteria. Other main characteristics include nonrespiring, non-spore forming, cocci or rods, and produce lactic acid as the major end product from the fermentation of carbohydrates.

Lactic acid bacteria (LAB) can be classified into two groups: homofermentative and heterofermentative. The homofermentative LAB are Lactobacillus delbrueckii, Lactobacillus plantarum, Lactobacillus bulgaricus, Lactobacillus helveticus, Lactobacillus casei, Streptococcus lactis, Streptococcus cremoris, Streptococcus faecalis, Streptococcus thermophilus and Pediococcus cerevisiae. The heterofermentative LAB are Leuconostoc mesenteroides, Lactobacillus cremoris, Lactobacillus brevis and Lactobacillus fermentum.

The biological production of lactic acid via microbial fermentation has been studied extensively by a many research groups (Hofvendahl and Hahn-Hagerdal, 2000). While the homofermentative LAB convert glucose almost exclusively into lactic acid, the heterofermentative LAB catabolize glucose into ethanol and $\mathrm{CO} 2$ as well as lactic acid. The homofermentative LAB usually metabolize glucose via the EmbdenMeyerhof pathway (i.e. glycolysis). Since glycolysis results only in lactic acid as a major end- product of glucose metabolism, two lactic acid molecules are produced from 
each molecule of glucose with a yield of more than $0.90 \mathrm{~g} / \mathrm{g}$. Only the homofermentative $\mathrm{LAB}$ are used for the commercial production of lactic acid (Yun, 2003). The present investigation was carried out, to study the potential of Lactic acid bacteria isolated from Curd and buttermilk samples from Local dairy products vendors of Himatnagar, Dist. Sabarkantha, Gujarat to produce Lactic acid using using whey supplemented with different components.

\section{Materials and methods}

\section{Preparation of whey}

Calcium lactate was added at boiling condition to cuddle down protein portion from milk. Coagulated protein was separated from whey by filtration technique.

\section{Microorganisms}

Potential Lactic acid producing bacteria from genus Lactobacillus were isolated on MRS medium from the Local dairy products vendors of Himatnagar, Dist. Sabarkantha, Gujarat.

\section{Preparation of Starter Culture}

The bacterial culture was grown in $50 \mathrm{~mL}$ of MRS medium in $250 \mathrm{~mL}$ Erlenmeyer flask. After sterilization, the medium was inoculated with a loopful of cells from agar stab and incubated at $37^{\circ} \mathrm{C}$ for $24 \mathrm{~h}$ under stationary conditions (Panesar et al., 2010)

\section{Fermentation medium}

Whey was supplemented with yeast extract $(0.75 \%, w / v)$, manganese sulphate $(20$ $\mathrm{mg} / \mathrm{L})$, and calcium carbonate $(1.5 \%, \mathrm{w} / \mathrm{v})$ (Panesar et al., 2010). The whey medium was sterilized at $121^{\circ} \mathrm{C}$ for $15 \mathrm{~min}$. The fermentation medium prepared in this way was used for the production of lactic acid using isolated strain.
Optimization of process parameters for lactic acid Production

Different process parameters such as $\mathrm{pH}$, inoculum size, temperature, carbon sources at different concentrations composition of fermentation medium and incubation period were optimized by varying the respective parameters to enhance lactic acid production.

\section{Lactic Acid Test}

Lactic acid was measured by modified Barker and Summerson (1941) method. Lactic acid was first oxidised with strong Sulphuric acid solution to acetaldehyde and then it was coupled with p-hydroxy diphenyl in the presence of cupric ions to yield a purple compound. The absorbance of purple compound was measured using spectrophotometer at $560 \mathrm{~nm}$.

\section{Effect of pH}

For optimizing the $\mathrm{pH}$ the fermentation medium was adjusted to different $\mathrm{pH}$ (5.0, 6.0, 6.5, and 8.0) and kept in $37^{\circ} \mathrm{C}$ shaker which runs at a speed of 150 revolutions per minute and the Lactic acid production was checked after $24 \mathrm{~h}$. The optimized $\mathrm{pH}$ was maintained for further work.

\section{Effect of Temperature}

Fermentation medium with adjusted $\mathrm{pH}$ was maintained at five different temperatures $\left(20,25,30,37,45\right.$ and $\left.50^{\circ} \mathrm{C}\right)$ by keeping them in the respective shakers running at a speed of $150 \mathrm{rpm}$ and the lactic acid production was estimated after $24 \mathrm{~h}$.

\section{Effect of inoculum size}

To study the influence of inoculum size on the lactic acid production, different inoculum levels $(1-5 \%, v / v)$ were added to 
the fermentation medium and the lactic acid production was estimated after $24 \mathrm{~h}$.

\section{Effect of Incubation Period}

To find out the optimal incubation time for the maximal lactic acid production, the fermentative medium inoculated with bacterial culture was incubated for $24 \mathrm{~h}, 48 \mathrm{~h}$, $72,96 \mathrm{~h}$ and $120 \mathrm{~h}$ under the above optimized conditions. End of the incubation period the lactic acid production was estimated.

\section{Results and discussion}

\section{Effect of pH}

The effect of $\mathrm{pH}$ on lactic acid production was estimated by using fermentation medium having a $\mathrm{pH}$ range of $5.0 \quad-8.0$ (Figure 1). The maximum lactic acid production $(38.86 \mathrm{gm} / \mathrm{L})$ was observed at $\mathrm{pH} 6.5$ on $24 \mathrm{~h}$. However, at higher and lower $\mathrm{pH}$ levels, a decrease in the both the function was observed, with significant decrease at $\mathrm{pH} 6.0$ and 7.0. $\mathrm{A} \mathrm{pH}$ range of 6.0-6.5 has been reported optimal for lactic acid production using $L$. casei strain (Krischke et al., 1991). However, pH 5.5 has been used for lactic acid production using $\mathrm{L}$. helveticus by (Ghaly et al., 2004). Panesar et al., (2010) observed maximum lactose conversion $(95 \%, \mathrm{w} / \mathrm{v})$ and lactic acid production $(33.48 \mathrm{gm} / \mathrm{L})$ was observed at $\mathrm{pH}$ 6.5. From the above observations, a $\mathrm{pH}$ 6.5 was considered optimal for maximum lactic acid production. In the subsequent experiments, the $\mathrm{pH}$ of the fermentation medium was adjusted to 6.5 .

\section{Effect of temperature}

To find the optimum temperature for lactic acid production, whey medium after inoculation was incubated at a temperature range of $20-50^{\circ} \mathrm{C}$. The lactose utilization and lactic acid production increased with increase in the temperature up to $37^{\circ} \mathrm{C}$; however, an insignificant decrease in the both the functions was found at $40^{\circ} \mathrm{C}$ (Figure 2). Other tested temperatures displayed low values of lactose utilization and lactic acid production. The maximum lactic acid production of $40.53 \mathrm{gm} / \mathrm{L}$ was observed at $37^{\circ} \mathrm{C}$.

The temperature is also one of the important factors, which influences the activity of metabolic cell enzymes. Enzymes are most active at optimum temperature and enzymatic reaction proceeds at maximum rate. However, below and above optimal temperature reaction rate is decreased which causes the problems in cell metabolism.

The optimal temperature for growth of lactic acid bacteria varies between the genera from 20 to $45^{\circ} \mathrm{C}$ (Wood et al., 1995). In fermentations using $L$. delbrueckii, and $L$. bulgaricus a temperature of $45^{\circ} \mathrm{C}$, or higher may be maintained (Buchta, 1983). L. helveticus, and L.acidophilus can be used in a temperature range of $37-45^{\circ} \mathrm{C}$. Krischke et al., (1991) used $37^{\circ} \mathrm{C}$ temperature for lactic acid production using $L$. casei. However, a temperature of $28^{\circ} \mathrm{C}$ has also been reported optimal for $L$. casei in a separate study (Nabi et al., 2004). Guha et al., (2013) observed maximum lactic acid production of $2.53 \mathrm{gm} / \mathrm{L}$ at $42^{\circ} \mathrm{C}$. Panesar et al., (2010) obseved maximum lactic acid production of $33.72 \mathrm{gm} / \mathrm{L}$ was observed at $37^{\circ} \mathrm{C}$.

From the above observations, a temperature range of $37-40^{\circ} \mathrm{C}$ was considered optimal for lactose conversion to lactic acid using bacterial cells; however, a temperature of $37^{\circ} \mathrm{C}$ was selected for further experimentation. 
Fig.1 Effect of pH

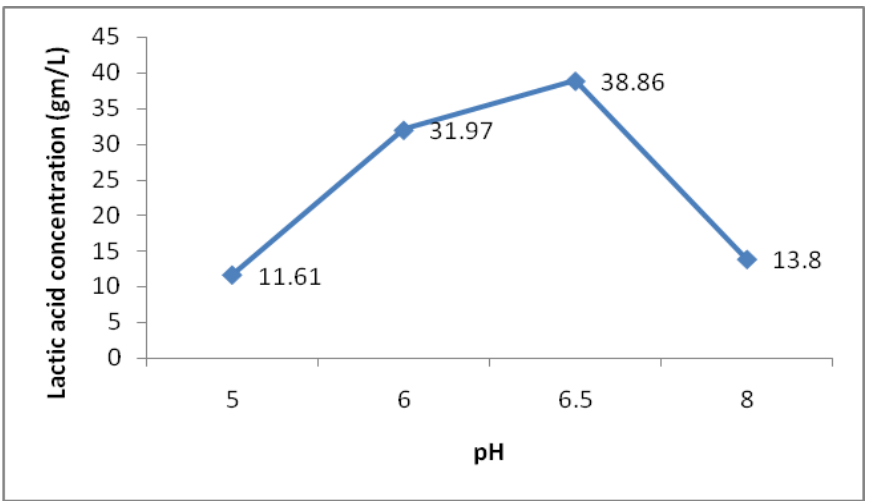

Fig.2 Effect of Temperature

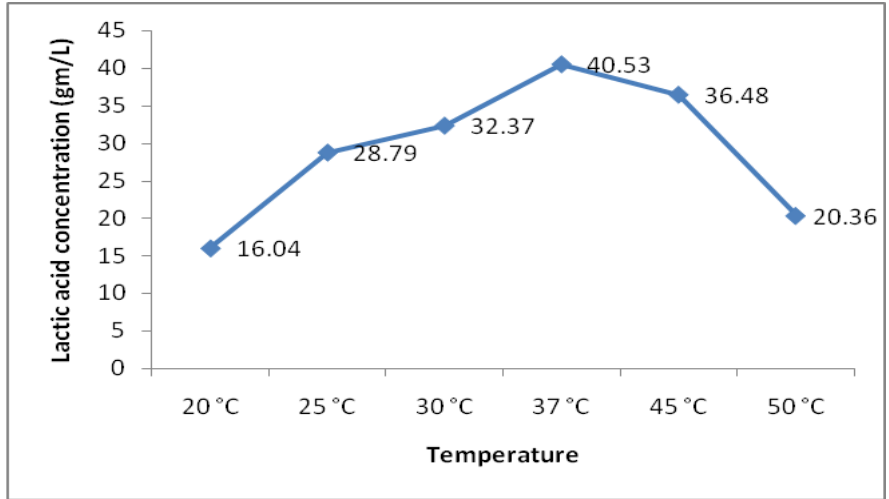

Fig.3 Effect of Inoculum Size

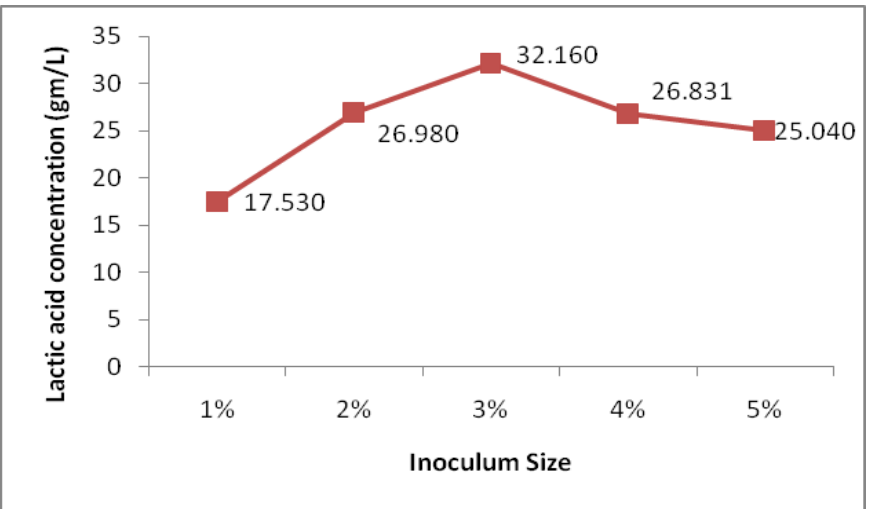


Fig.4 Effect of Incubation Period

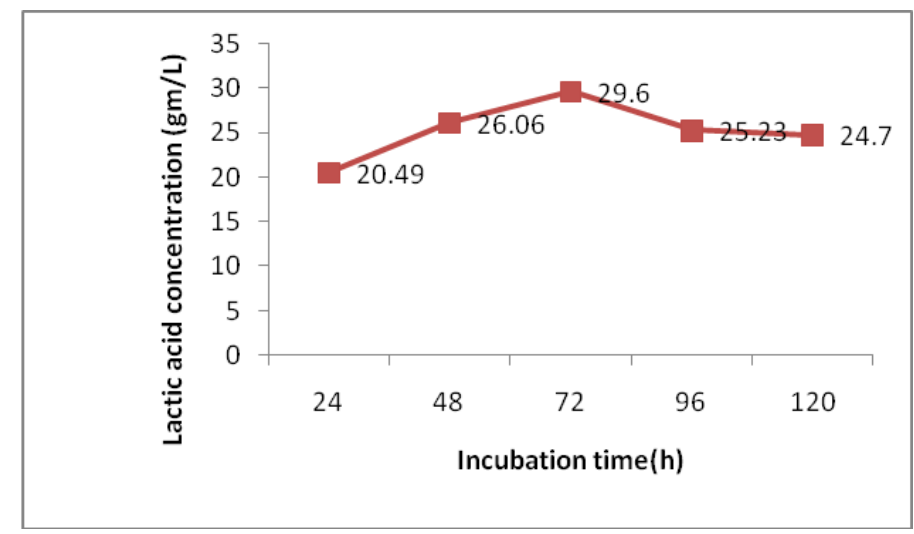

\section{Effect of Inoculum Size}

To study the influence of inoculum size on the lactic acid production, different inoculum levels $(1-5 \%, \mathrm{v} / \mathrm{v})$ were added to the fermentation medium (Figure 3). The lactose utilization and lactic acid production increased with the increase in inoculum size up to $3 \%(\mathrm{v} / \mathrm{v})$, thereafter no improvement in both the functions was observed.

The maximum lactic acid production of $32.16 \mathrm{gm} / \mathrm{L}$ was observed with $3 \%(\mathrm{v} / \mathrm{v})$ inoculum of bacterial culture. The low lactic acid production at $1 \%(\mathrm{v} / \mathrm{v})$ inoculum level could be attributed to the low density of starter culture. The use of $2 \% \quad(\mathrm{v} / \mathrm{v})$ inoculum for the lactic acid production has been reported in earlier studies also (Roy $e t$ al., 1986; Gandhi et al., 2000). 3\%, v/v inoculum has also been used for lactic acid production (Chiarini et al., 1992). Guha et al., (2013) observed maximum lactic acid production of $2.52 \mathrm{gm} / \mathrm{L}$ with $4 \%(\mathrm{v} / \mathrm{v})$ inoculum of bacterial culture. Panesar et al., (2010) observed maximum lactic acid production of $33.72 \mathrm{gm} / \mathrm{L}$ was observed with $2-4 \% \quad(\mathrm{v} / \mathrm{v})$ inoculum of bacterial culture.

From the above observations, an inoculum of $3 \%(\mathrm{v} / \mathrm{v})$ could be considered optimal for achieving maximum lactic acid production using $24 \mathrm{~h}$ old bacterial culture. $3 \%(\mathrm{v} / \mathrm{v})$ inoculum size was used in the subsequent studies.

\section{Effect of Incubation Period}

To find out the optimal incubation time for the maximal lactose utilization and lactic acid production, the whey medium inoculated with bacterial culture was incubated for Different time at 24, 48, 72, 96 and $120 \mathrm{~h}$ under the above optimized conditions. The samples were drawn at specified time intervals and the results obtained are presented in Figure. 4. As evident from the results, an increase in lactose utilization and subsequent lactic acid production was found up to $72 \mathrm{~h}$ and thereafter no improvement in both the functions was observed. This could be attributed to the growth of the culture reached to the stationary phase and as a consequence of metabolism, microorganisms continuously change the characteristics of the medium and the environment. A maximum lactic acid production of $29.6 \mathrm{gm} / \mathrm{L}$ was observed after $72 \mathrm{~h}$ of incubation. The reduction in fermentation period is additionally advantageous to improve the economics of the process. Therefore, an incubation time of 
$72 \mathrm{~h}$ was considered optimal for maximum lactose conversion to lactic acid. The incubation period of $48 \mathrm{~h}$ has been generally used for lactic acid production using different lactobacilli cultures (Chiarni et al., 1992; Gandhi et al., 2000; Kumar et al., 2001). Panesar et al., (2010) observed maximum lactic acid production of 33.73 $\mathrm{gm} / \mathrm{L}$ after $36 \mathrm{~h}$ of incubation. Guha et al., (2013) observed maximum lactic acid production of $2.58 \mathrm{gm} / \mathrm{L}$ was observed after $48 \mathrm{~h}$ of incubation. The reduction in fermentation period is additionally advantageous to improve the economics of the process. Therefore, an incubation time of $48 \mathrm{~h}$ was considered optimal for maximum lactose conversion to lactic acid.

In conclusion, Whey is the waste byproduct of milk industry, which can be used for lactic acid production. From the observations made during the process optimization studies, it could be concluded that maximum sugar conversion to lactic acid was obtained with the process conditions of $\mathrm{pH} 6.5$, temperature $37^{\circ} \mathrm{C}$ and inoculum size $3 \%(\mathrm{v} / \mathrm{v})$ with an incubation of $48 \mathrm{~h}$. The different optimal conditions reported by various workers for maximum lactic acid production could be explained by the differences in the nature of the strains and medium composition used in their studies. The above optimized process parameters can be used in scale up studies in further investigations.

\section{References}

Barker, S.B., Summerson, W.H. 1941. The colorimetric determination of lactic acid in biological material. J. Biol. Chem., 138: 535-554.

Buchta, K. 1983. Lactic Acid: In Biotechnology. Germany: $\mathrm{VCH}$ Verlag Weinheim.
Chiarini, L., Mara, L., Tabacchioni, S. 1992. Influence of growth supplements on lactic acid production in whey ultra filtrate by Lactobacillus helveticus. Appl. Microbiol. Biotechnol., 36: 461464.

Gandhi, D.N., Patel, R.S., Wadhwa, B.K., Bansal, N., Kaur, M., Kumar, G. 2000. Effect of agro-based byproducts on production of lactic acid in whey permeate medium. J. Food Sci. Technol., 37: 292-295.

Ghaly, A.E., Tango, M.S.A., Mahmood, N.S., Avery, A.C. 2004. Batch propagation of Lactobacillus helveticus for production of lactic acid from lactose concentrated cheese whey with microaeration and nutrient supplementation. World J. Microbiol Biotechnol., 20: 65-75.

Guha, A., Banerjee, S., Bera, D. 2013. Production of Lactic acid from Sweet meat industry waste by Lactobacillus delbruki. IJRET., 630-634.

Hofvendahl, K., Hahn-Hägerdal, B. 2000. Factors affecting the fermentative lactic acid production from renewable resources. Enzyme Microb Tech., 26: 87-107.

Ilmen, M., Koivuranta, K., Ruohonen, L., Suominen, P., Penttila, M. 2007. Efficient production of Llactic acid from xylose by Pichia stipitis. App. Environ. Microb., 73: 117-123.

Kharras, G.B., Sanchez-Riera, F., Severson, D.K. 1993. Polymers of lactic acid. In: Molby, D.B., Ed., Plastics from microbes: Microbial synthesis of polymers and poly- mer precursors. Hanser Publishers, Munich, 93-137.

Krischke, W., Schroder, M., Trosch, W. 1991. Continuous production of Llactic acid from whey permeate by immobilized Lactobacillus casei subsp casei, Appl. Microbiol. Biotechnol., 34: 573-578. 
Kumar, S., Jha, Y.K., Chauhan, G.S. 2001. Process optimization for lactic acid production from whey using Lactobacillus strains. J. Food Sci. Technol., 38: 59- 61.

Nabi, B., Gh. R., Baniardalan, P. 2004. Batch and continuous production of lactic acid from whey by immobilized lactobacillus. J. Environ. Studies, 30: 47-53.

Narayanan, N., Roychoudhary, P.K., Srivastava, A. 2004. L (+) Lactic acid fermentation and its product polymerization. Electronic $J$. Biotechnol., 7: 46-9.

Ohris, S.P., Joshi, B.K. 1961. Composition of camel milk. Indian Vet. J., 38(5): 14-5.

Panesar, P.S., Kennedy, J.F., Knill, C.J., Kosseva, M. 2010. "Production of L(+) Lactic Acid using Lactobacillus casei from Whey. Braz. Arch. Biol. Technol., 53: 219-226.

Roy, D., Goulet, J., LeDuy, A. 1986. Batch fermentation of whey ultrafiltrate by
Lactobacillus helveticus for lactic acid production. Appl. Microbiol. Biotechnol., 24: 206-213.

TIFAC, Vision 2020 reports. Technology Linked Business Opportunity Publications, Code No. TMS 157, 4.

Wee, Y.J., Yum, J.S., Kim, D., Ryu, H.W. 2006. Batch and repeated batch production of $\mathrm{L}(+)$-lactic acid by Enterococcus faecalis RKY1 using wood hydrolyzate and corn steep liquor. J. Ind. Microbiol. Biot., 33: 431-35.

Wood, B.J.B., Holzapfel, W.H. 1995. The Genera of Lactic Acid Bacteria, Glasgow: Blackie Academic \& Professional, USA.

Yun, J.S., Wee, Y.J., Ryu, H.W. 2003. Production of optically pure L(+)lactic acid from various carbohydrates by batch fermentation of Enterococcus faecalis RKY1. Enzyme Microb. Technol., 33: 416-423.

\section{How to cite this article:}

Sweta A. Patel and Samir C. Parikh. 2016. Production of Lactic Acid from Whey by Lactobacillus sp. Isolated from Local Dairy Products. Int.J.Curr.Microbiol.App.Sci. 5(5): 734741. doi: http://dx.doi.org/10.20546/ijcmas.2016.505.074 